\title{
ESTÉTICAS DISLOCADAS. PRESENCIAS NÓMADAS EN EL ESCENARIO URBANO
}

Héctor Castañón Reyes*

RESUMEN: Las migraciones de sentido condicionan la mirada del espectador urbano respecto a lo que consideran bello, aceptable, deseable o significativo en la ciudad. Las presencias nómadas en el espacio público, vistas como estéticas fuera de lugar o dislocadas, representan esas irrupciones en el orden cotidiano urbano que abren la puerta para preguntarse por las circunstancias que producen y configuran lo urbano como espacio disputado de encuentro.

PALABRAS CLAVE: indígenas, migrantes, mercados, informalidad, ciudad.
DisLOCATED AESTHETICS.

NOMADIC PRESENCE IN THE URBAN SCENE

ABSTRACT: The migrations of sense shape the urban viewer's gaze regarding what he or she considers beautiful, acceptable, desirable or significant in the city. The nomadic presence in public spaces, seen as aesthetics that are out of place or dislocated, represents these irruptions in the urban daily order, which opens the door to questioning the circumstances that produce and form the urban environment as a contested space of encounter.

KEYWORDS: indigenous people, migrants, markets, informality, city

*Asociado del colectivo de investigación independiente Centro de Infotectura y Tecnología Aplicada A.C. 


\section{ESTÉTICAS DISLOCADAS. \\ PRESENCIAS NÓMADAS \\ EN EL ESCENARIO URBANO}

Al hablar de una jerarquía, hablamos de la intervención de una entidad jerarquizadora que opera para organizar nuestras formas de entender, percibir y valorar el mundo; cuando hablamos de orden, normalmente hablamos de un conjunto de relaciones que se ha estabilizado para configurar lo que Rancière ${ }^{1}$ definía como régimen de sensibilidad, que puede entenderse como el sistema de las formas que a priori determinan lo que se va a experimentar, en una delimitación de tiempos y espacios, de lo visible y lo invisible, de la palabra y el ruido, de lo que define a la vez el lugar y el dilema de la política como forma de experiencia, refiriéndose a lo que se ve y a lo que se puede decir, a las propiedades de los espacios y los posibles del tiempo.

Lo que veremos a continuación son las reconfiguraciones estéticas que produce el dislocamiento como experiencia para la construcción de una nueva sensibilidad, en función de cómo se construye el sentido y se forma la mirada.

Se consideran tres tipos de dislocamientos: dislocamientos forzados, los no intencionados por el sujeto, a los que somos obligados; dislocamientos disruptivos, que reflejan una ruptura y posición intencionados; y dislocamientos transitorios, que no necesariamente responden a una intencionalidad, sino que se dan circunstancialmente por el flujo constante en el escenario urbano.

\footnotetext{
${ }^{1}$ Jacques Rancière, Le partage du sensible, 2000, París, La Fabrique.
} 
El primer caso es el de las presencias nómadas en el espacio público de los migrantes; el segundo se trata de la presencia indígena en la ciudad, y el tercero es el caso de los mercados callejeros.

Si hablamos de sujetos fuera de lugar, de presencias nómadas, uno de los casos más claros es el de las y los migrantes. ¿Qué experiencia estética genera su tránsito por las ciudades? La ciudad de Guadalajara, por ejemplo, se localiza en la ruta del ferrocarril del centro del país hacia Nogales; es un paso para las migraciones centroamericanas y del sureste mexicano. Durante muchos años pasaron invisibilizados en el espacio público; sin embargo, ahora son cada vez más visibles en los cruceros de toda la ciudad, porque en su camino hacia el norte tienen que hacer estancias para recolectar dinero y aprovisionarse.

En algunos sectores de la población se ha generado una gran discusión sobre la mala imagen que provocan los migrantes en el espacio púbico de la ciudad. Se encontraban principalmente cerca de las vías del tren, pero ahora se han ido instalando en muy distintos puntos de la ciudad. La imagen siguiente es de un asentamiento llamado Pueblo Quieto, que está enclavado en una zona residencial de Guadalajara. La presencia de los migrantes es cada vez más habitual, tanto la nómada como la seminómada y la permanente.

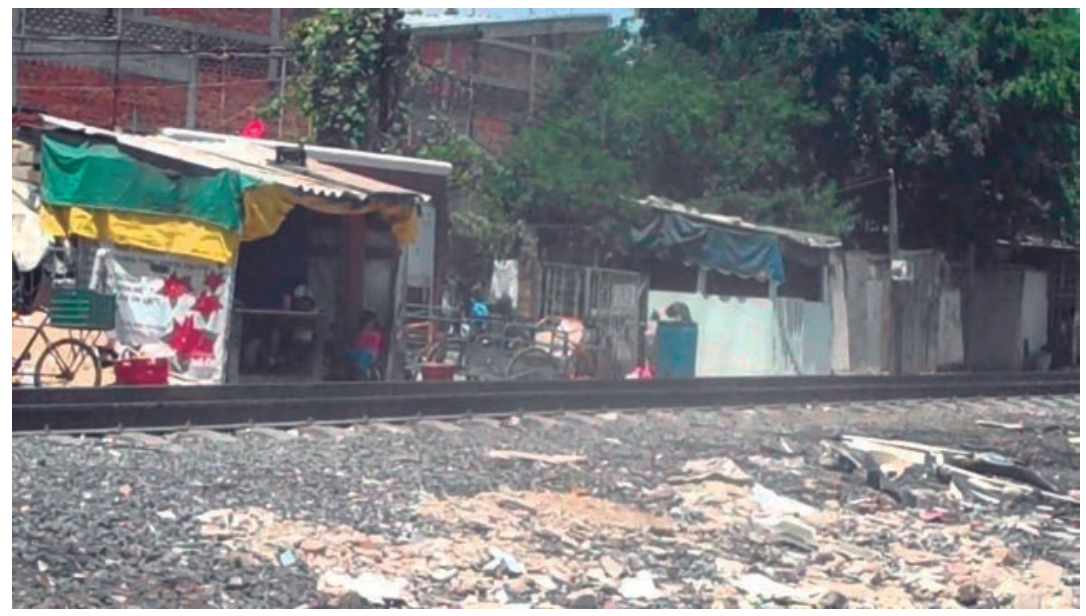

Pueblo Quieto, Guadalajara, Jalisco. Fuente: Héctor Castañón.

Es importante entender cómo se producen estas configuraciones precarias que terminan incorporándose a la ciudad, por las condiciones en que la propia ciudad fuerza a los migrantes a usar el espacio. 
Como se ha dicho, la presencia de migrantes se da sobre todo a lo largo de las vías del tren, a las que normalmente la ciudad les da la espalda. Pero con la aparición del proyecto turístico Tequila Express, en el que un tren de pasajeros lleva turistas del centro de Guadalajara al pueblo de Tequila, se produce un importante choque estético entre el escenario de las vías como espacio de desplazamiento y producción de los procesos migratorios y el de uno de los atractivos turísticos más importantes de Guadalajara.

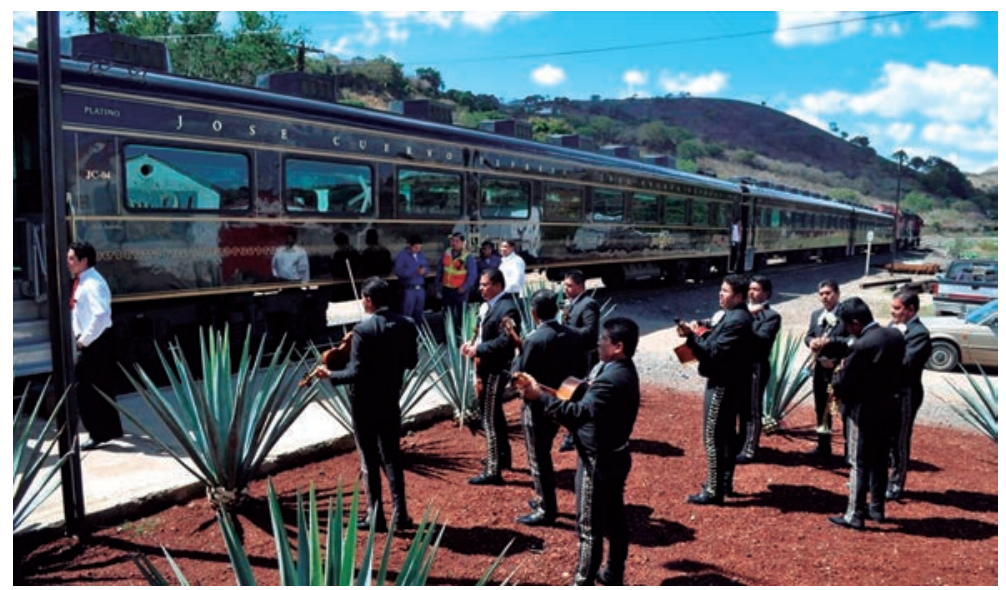

Tequila Express. Fuente: Tequila Casa José Cuervo.

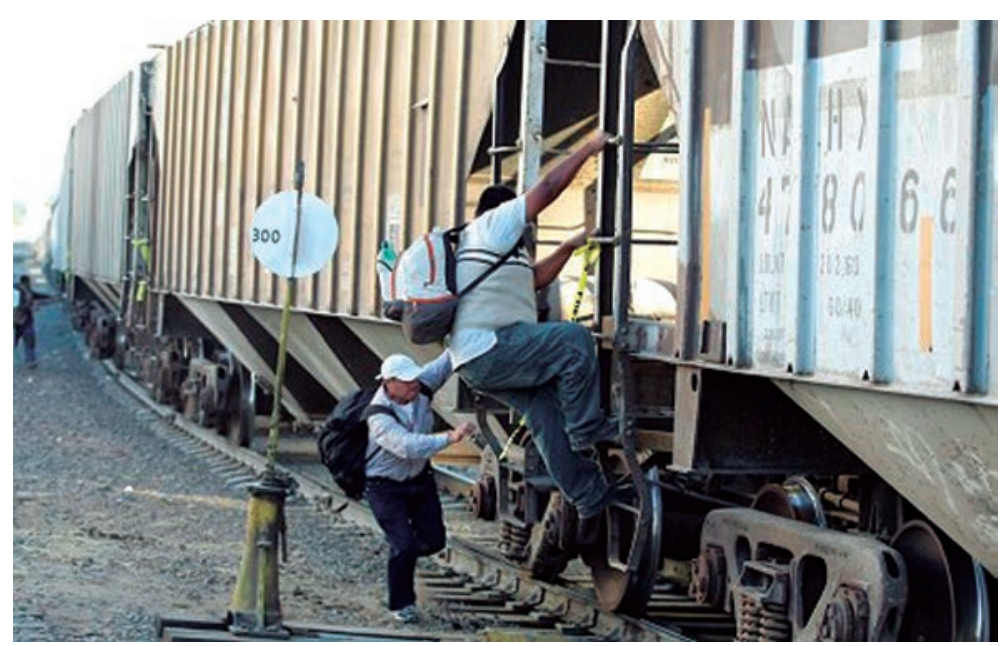

Migrantes subiendo al tren. Fuente: Concienciapublica.com.mx. 
La imagen de los migrantes subiendo al tren alude a una transgresión de los límites establecidos para conservar un acomodo con el que se pretende que la ciudad dé su mejor cara al turismo; sin embargo, la fuerte presencia de migrantes en los espacios públicos de Guadalajara se ha vuelto problemática, más allá de su connotación delincuencial (la de quienes rebasan los linderos que la sociedad les ha impuesto para mantener cierto orden). Sus acciones y sus modos de estar en el espacio público se han revisado desde sus propios contextos y se han abstraído de la situación urbana específica, para abordar lo que hacen desde otros planos de análisis.

En la siguiente imagen se muestra el montaje escénico de la obra $L a$ Bestia, historias que migran, ganadora del premio Jalisco a la Juventud 2012 y apoyada por el Fondo Nacional para la Cultura y las Artes. La pieza representa la migración en Centroamérica mediante danza contemporánea. La Bestia es el nombre que se da al tren de carga que lleva los migrantes a la frontera.

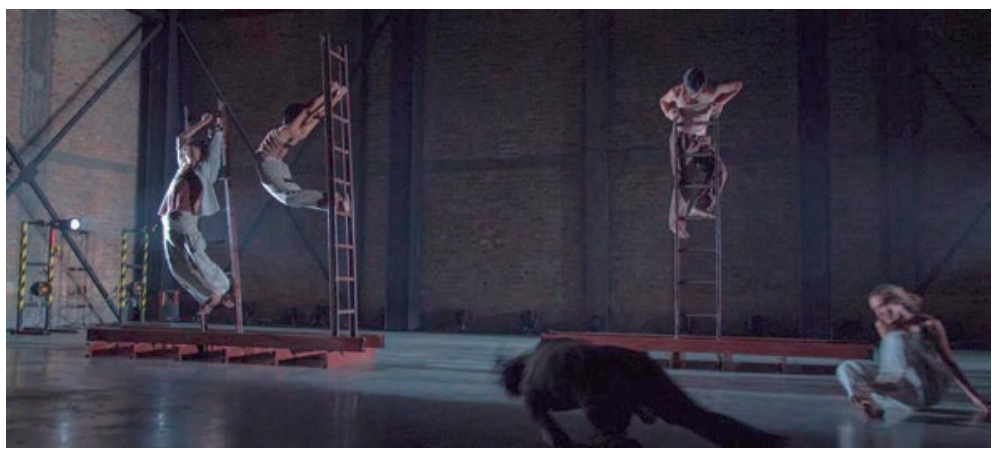

Montaje escénico La Bestia, historias que migran. Fuente: LARVA.

Se trata de una resignificación de lo que habitualmente vemos en el espacio público. Esta resignificación ha pasado a otros planos, por ejemplo, en Guadalajara ya se celebra periódicamente el Festival de la Bestia, un festival cultural en donde las historias de los migrantes se convierten en música e imagen y que tienen el propósito de modificar la relación afectiva con los migrantes. 


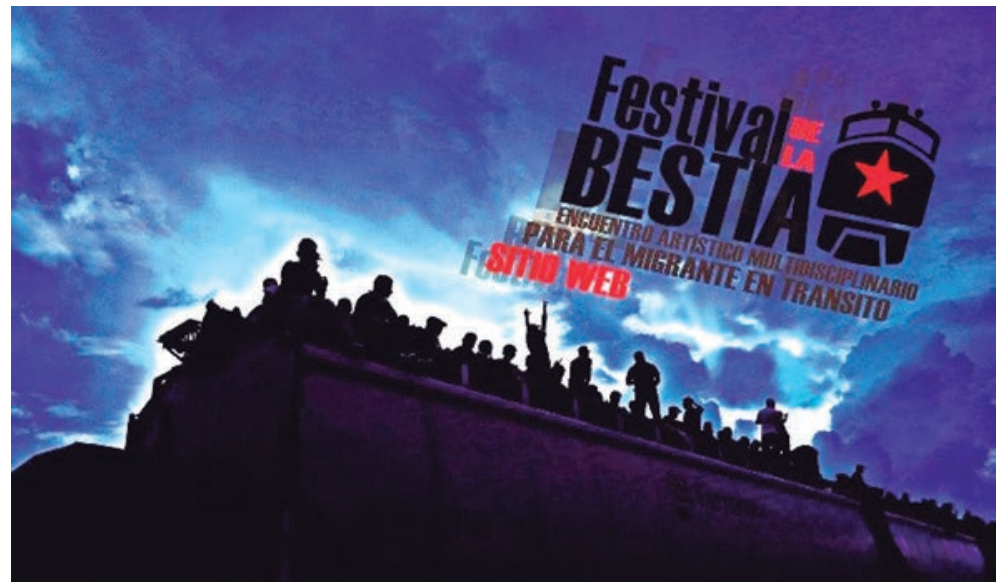

Cartel del Festival de La Bestia. Fuente: festivaldelabestia.blogspot.mx

En el festival Gises por la Paz se busca humanizar la presencia y figura del migrante visibilizando los dramas por los que atraviesa, de manera que cada vez que se mire a un migrante en la ciudad, se entiendan las condiciones que lo obligaron a emigrar y la vida que ha dejado atrás, para modificar la forma de ver a los migrantes en el espacio público.

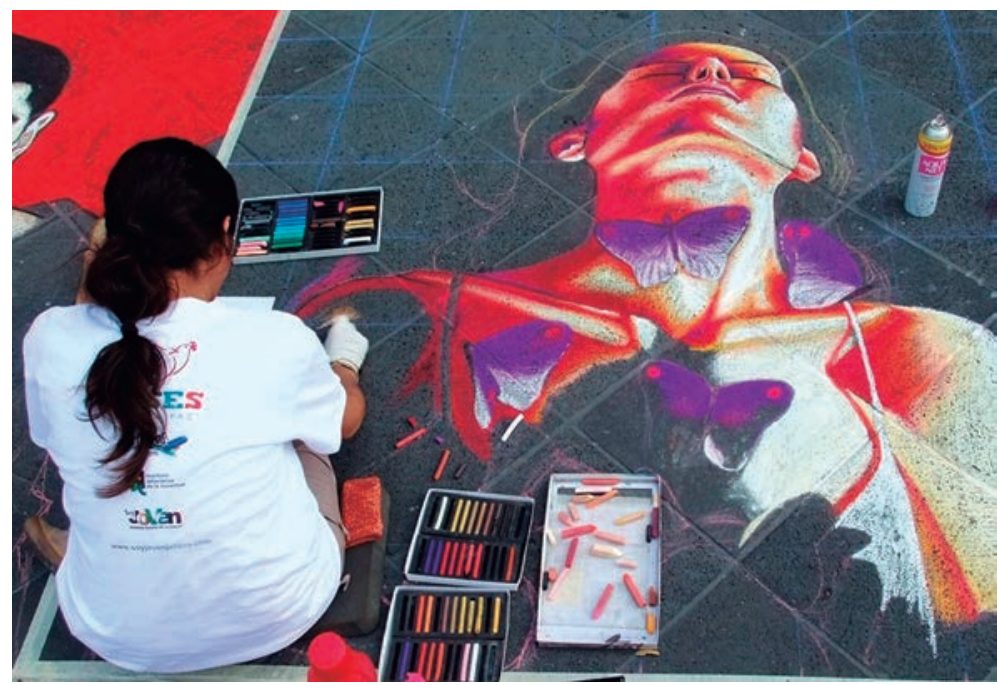

Imagen del festival "Gises por la Paz". Fuente: Proyecto Diez. 
La siguiente imagen es de una cerveza artesanal tapatía llamada "La Bestia", que se expresa en otro plano emotivo: el de las resistencias. Los afectos que se han ganado los migrantes han provocado, incluso, que sean percibidos como héroes y sobrevivientes de la tiranía cotidiana. Esta imagen de ellos es radicalmente opuesta a la que proyectaban primero en el espacio público. Los testigos urbanos pasaron de ser víctimas de una presencia extraña a ser victimarios que alimentan un sistema de exclusión y desigualdad.

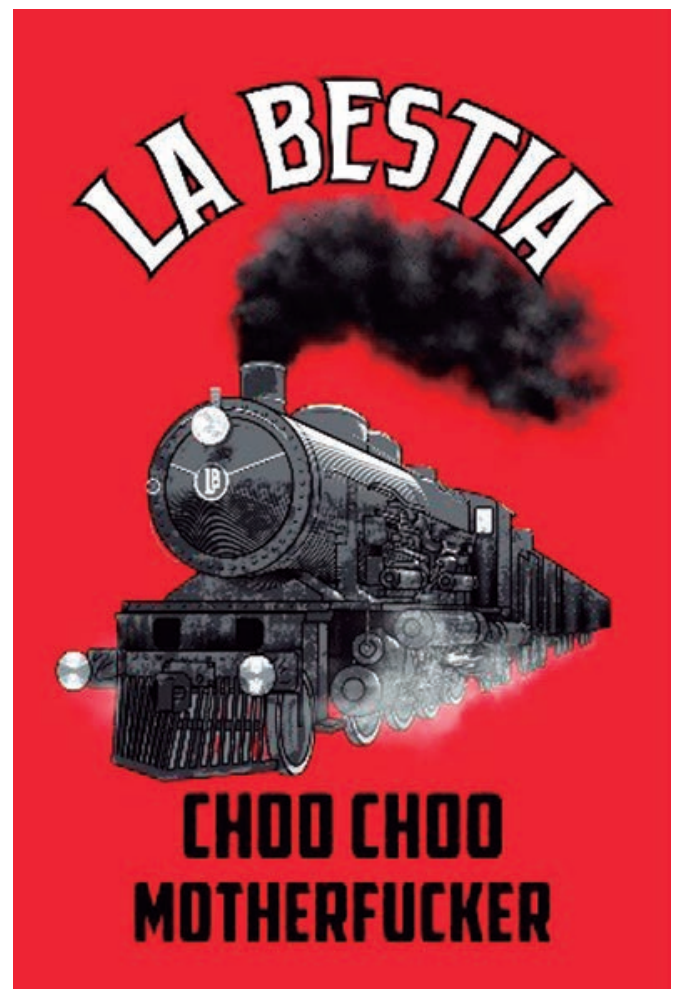

Cartel de la cerveza artesanal La Bestia.

Tomo aquí una cita del trabajo de la antropóloga Sara Corona, ${ }^{2}$ que en Pura imagen plantea que la construcción de las imágenes no es individual ni libre, y que para hacerse entender, sus realizadores se remiten a estereotipos y fórmulas de imágenes anteriores, así como a los discursos que circulan en el contexto. Las imágenes, más que percepciones, son construcciones sociales que pueden

${ }^{2}$ Sarah Corona Berkin (coord.), Pura imagen, 2012, México, Conaculta. 
ser reinterpretadas según distintas experiencias discursivas. Esto es lo que está pasando con nuestra percepción de los migrantes en la ciudad: al situarnos en una posición distinta en el complejo entramado social del fenomeno migratorio, pasamos de condenarlos a sublimarlos.

En el caso de las estéticas dislocadas, sucede lo contrario: un desplazamiento de lo sublime a lo condenable. La siguiente imagen es arte wixárika (huichol).

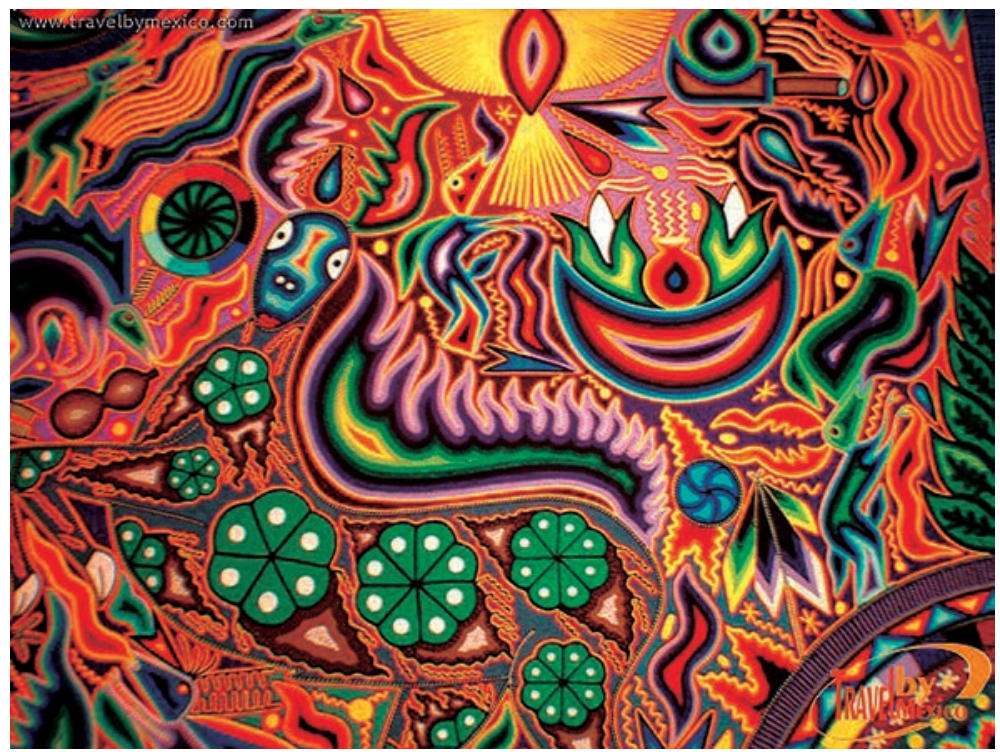

Arte wixárika. Fuente: Héctor Castañón.

Estas imágenes se venden en galerías de todo el mundo y son muy valoradas; reflejan la cosmovisión de un pueblo y se tienen como lo mejor del arte de los grupos étnicos en México. Sin embargo, la mirada del observador urbano sobre la presencia indígena se ha ido condicionando por la imagen publicitaria de los programas sociales. Cada vez que se nos presenta la figura indígena en las narrativas de las políticas públicas, predomina una estética del tedio, una estética pacificadora y desmovilizadora dirigida a los observadores urbanos. Al indígena se le termina relegando imaginariamente a su lugar de origen, alejado, como receptor de beneficencia social, como objeto de las políticas públicas. ${ }^{3}$

${ }^{3}$ Carlos Barba, "La construcción visual de la pobreza en el régimen discursivo de los programas sociales en México", en Sarah Corona (coord.), Pura Imagen, 2012, México, Conaculta. 


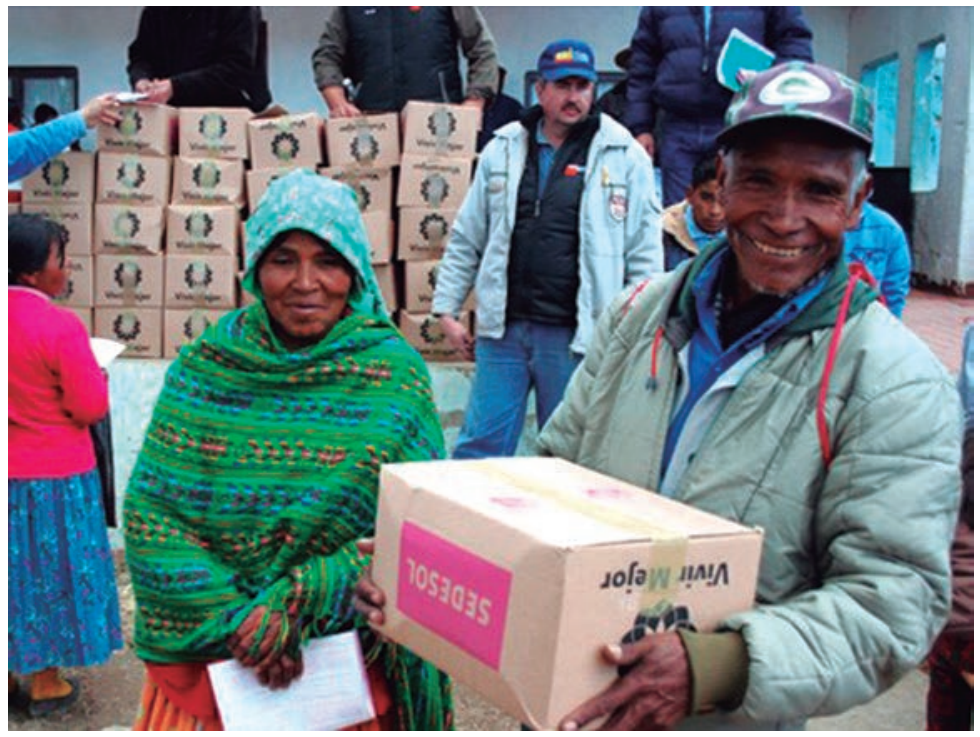

Indígenas beneficiarios de un programa público. Fuente: Sarah Corona, 2012.

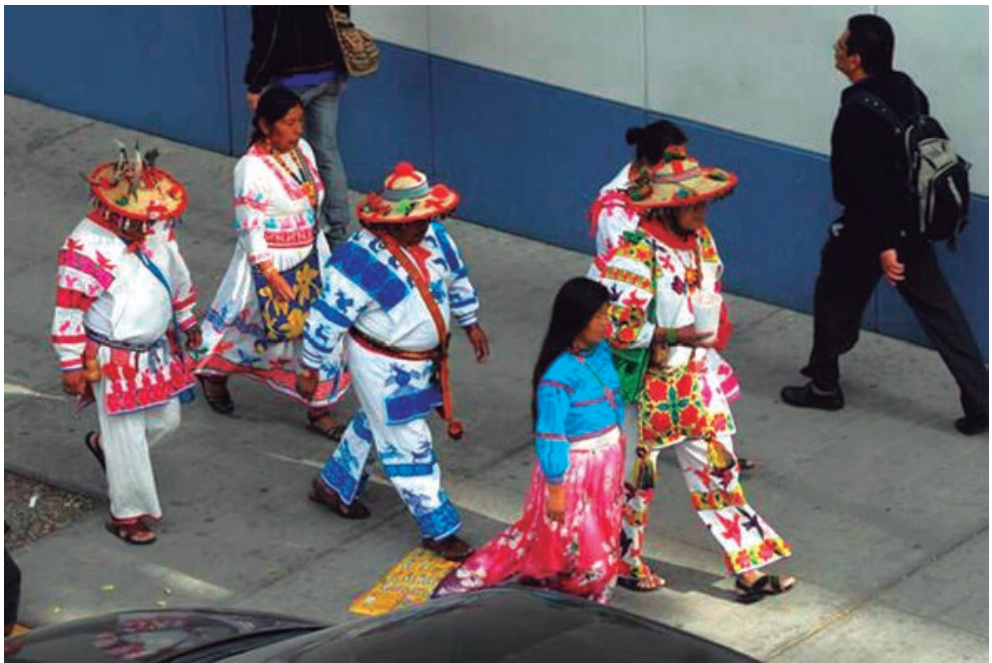

Indígenas wixaritaris en Guadalajara. Fuente: PulsoDF.

Pero ¿qué pasa con el indígena en el entorno urbano? Retomando a Carlos Barba, que dice que la fotografía estereotipada del indígena lo caracteriza con una escena arcaica, inamovible, vulnerable y pueril, el peligro de 
una imagen homogénea como la de la fotografía de indígenas es que recalca la diferencia, la jerarquiza y excluye a estos sujetos del espacio público y de la política.

Mediante la imagen, los indígenas son excluidos, y a través de los discursos, se da forma a la mirada del observador urbano, de manera que cuando ve a un indígena en el espacio público, deja de ser indígena, deja de ser artista, deja de pertenecer a su etnia y se convierte en un vendedor ambulante, en un indio que, precisamente por estos discursos de poder, por estas etiquetas, al moverse al plano urbano es precarizado, como se evidencia en los elementos con los que realiza su actividad: son cajas de cartón, porque no sabe si se las van a quitar. Los indígenas se instalan en lugares de los que es fácil huir y sus instalaciones como comerciantes son precarias, justamente porque el poder precariza la forma.

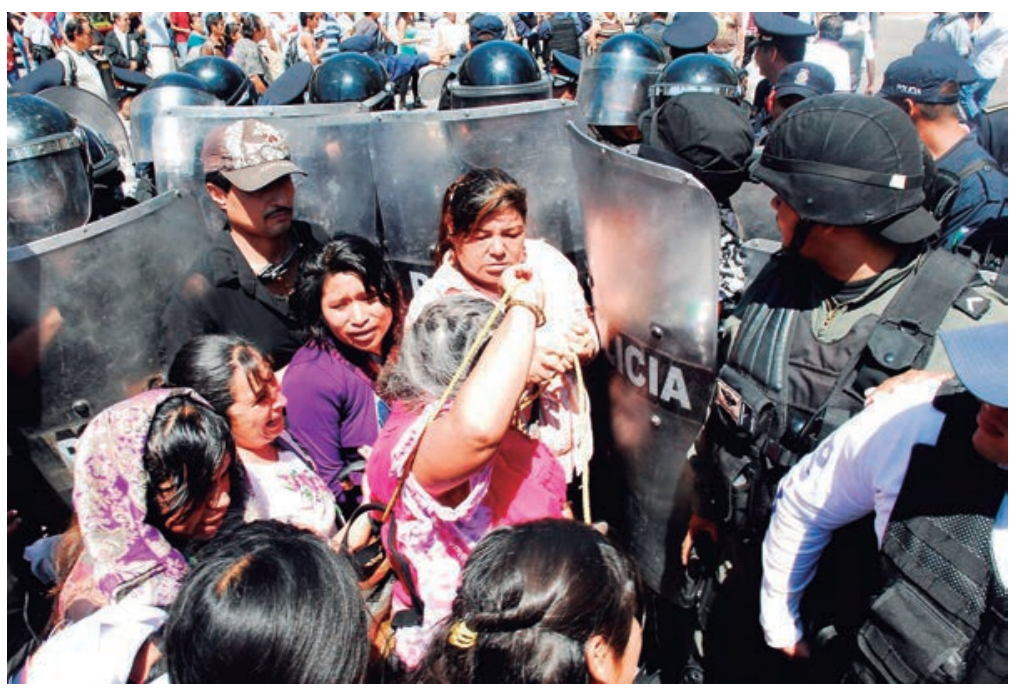

Policías encapsulan una manifestación de vendedoras indígenas en el centro de Guadalajara. Fuente: La Jornada.

Muchas veces, en las políticas públicas dirigidas los indígenas urbanos aparecen como transgresores o delincuentes, como comerciantes ambulantes, ya no como una cultura indígena. La ciudad, en su discurso de orden, excluye a las comunidades indígenas y les da una condición totalmente distinta que en otros planos de comprensión. 
El tercer caso de problematización de la idea de lo bello en la ciudad es el de los mercados públicos. En este caso también hay presencia indígena, pues se encuentra su cultura en los mercados públicos desde el origen de la ciudad.

La siguiente fotografía es del río San Juan de Dios, cuando todavía cruzaba la ciudad de Guadalajara. Al fondo se aprecia el mercado Libertad.

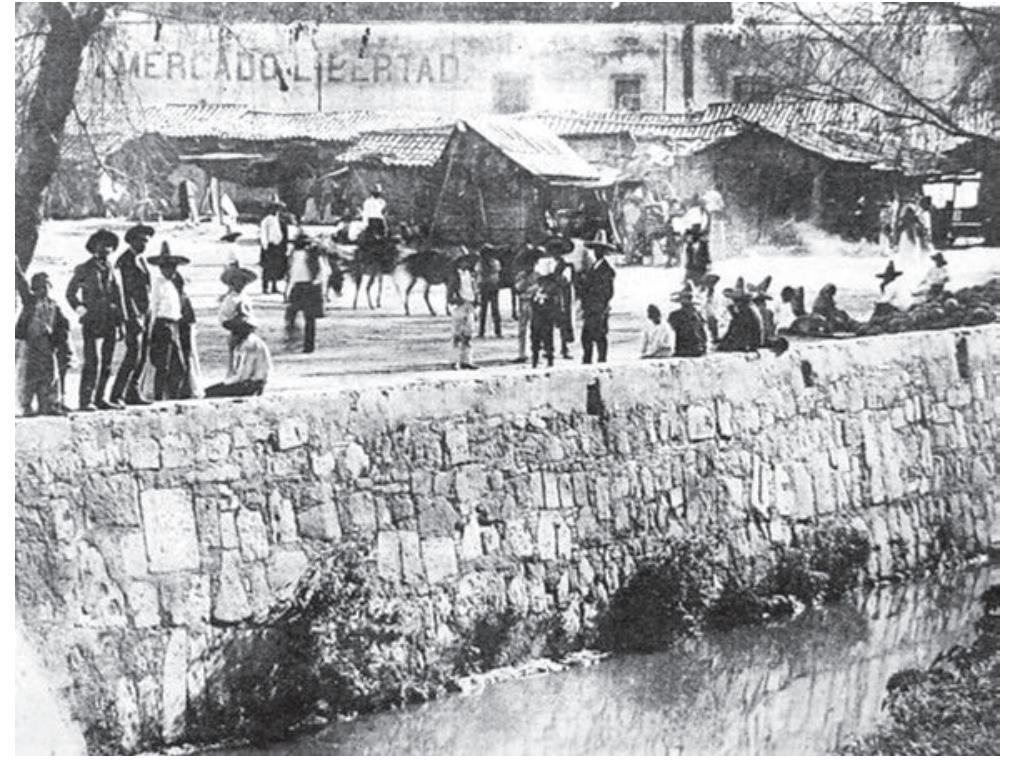

Río San Juan de Dios y mercado Libertad, Guadalajara. 1890.

Fuente: Lostapatios.blogspot.mx.

El mercado de San Juan de Dios es hoy de los principales atractivos turísticos de Guadalajara, es uno de los espacios más visitados por turistas locales, regionales e internacionales, y una de las piezas arquitectónicas del siglo XX más relevantes en el primer cuadro de la ciudad, obra de Alejandro Zohn. Cuando se incorporan las dinámicas socioculturales históricas y se estabilizan en presencias urbanas permanentes, se obtiene el resultado actual del mercado de San Juan de Dios, en cuya renovación se observaron estas dinámicas, impulsadas sobre todo por comerciantes y por las tradiciones de los mercados indígenas. Sin embargo no ocurre así en todos los casos. 


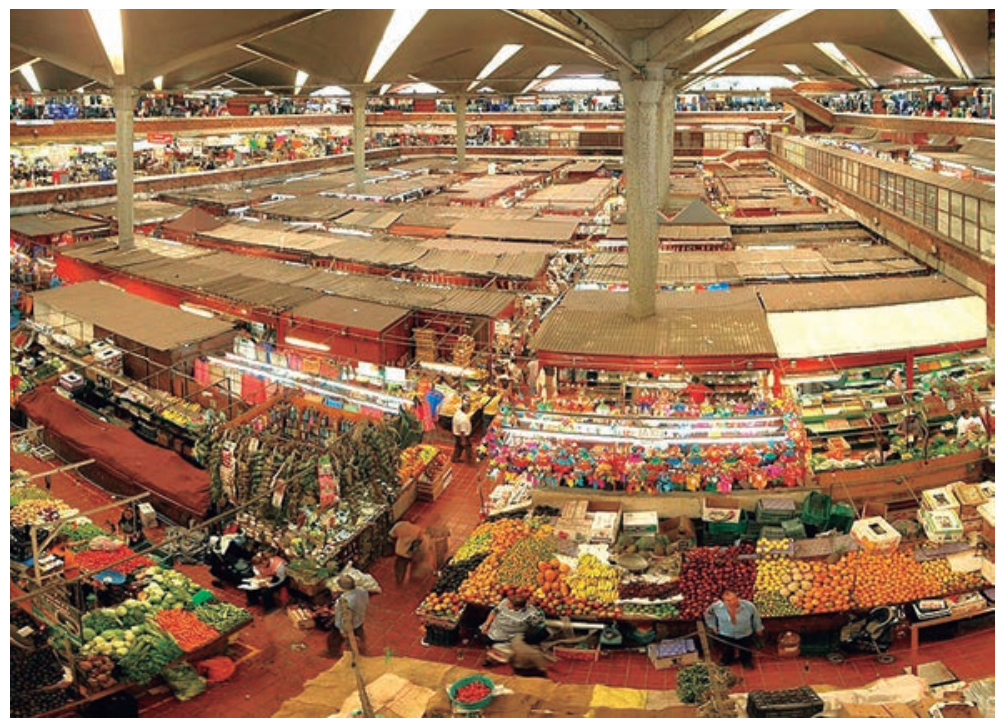

Mercado de San Juan de Dios. Guadalajara, 2015. Fuente: C7 Jalisco.

Otro mercado significativo de Guadalajara es el Corona, muy cercano al centro de la ciudad. En esta fotografía de principios de siglo se aprecia el comercio en el espacio público y una notable presencia y actividad indígena, ya estabilizada en este espacio.

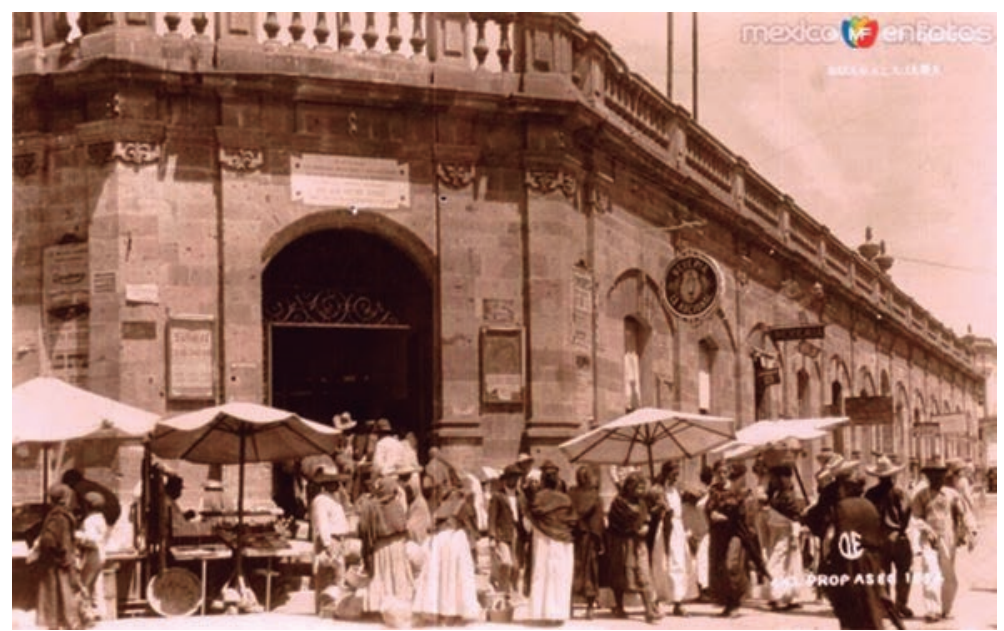

Mercado Corona, Guadalajara 1926. Fuente: Imágenes Hstóricas de Guadalajara. 
El mercado sufrió un primer gran incendio en 1917 y el segundo a mediados de 2014. Puede apreciarse en la siguiente imagen lo cerca que está el mercado Corona de la catedral de Guadalajara. El mercado quedó totalmente en ruinas y fue necesario reconstruirlo por completo.

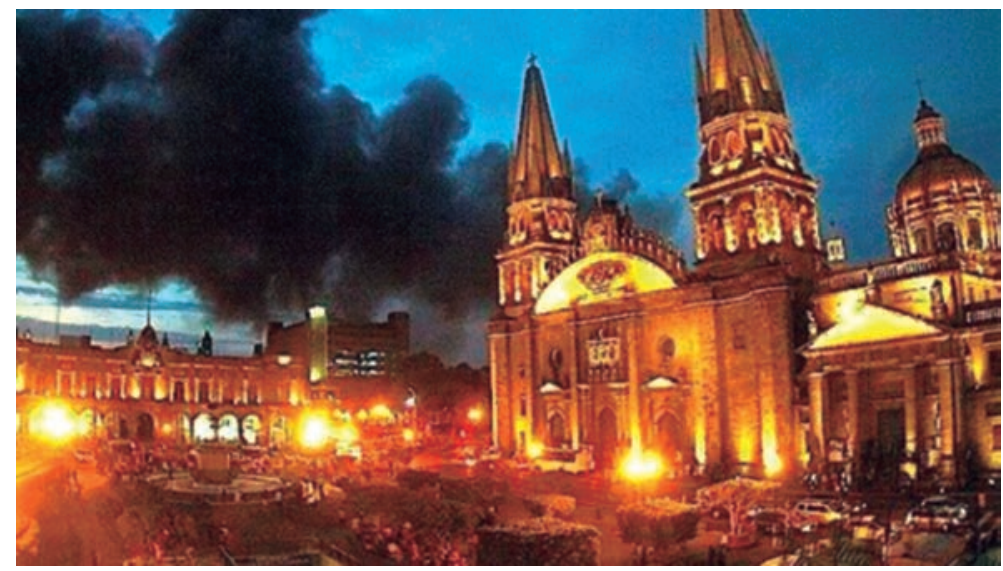

Humo del incendio del Mercado Corona. Guadalajara, 2014.

Fuente: Unión Jalisco.

Al plantearse las dificultades de cómo reconstruir el mercado en las condiciones políticas, sociales y económicas actuales, ¿se reconocería de nuevo la presencia histórica de los comerciantes o se transformaría en un espacio con otra lógica y actores ajenos al lugar? Se lanzó una convocatoria para reunir propuestas arquitectónicas, las cuales dieron lugar a varios dislocamientos del mercado vivido al mercado proyectado.

En esta primera imagen propuesta se ofrece una panorámica general del contexto, para entender cómo se insertaría la nueva obra. Expresa una búsqueda de armonía con el lugar y su estética, la cual es a su vez reflejo de lo que la ciudad y su gente han hecho de este espacio y su disputa simbólica desde la época de la Colonia. 


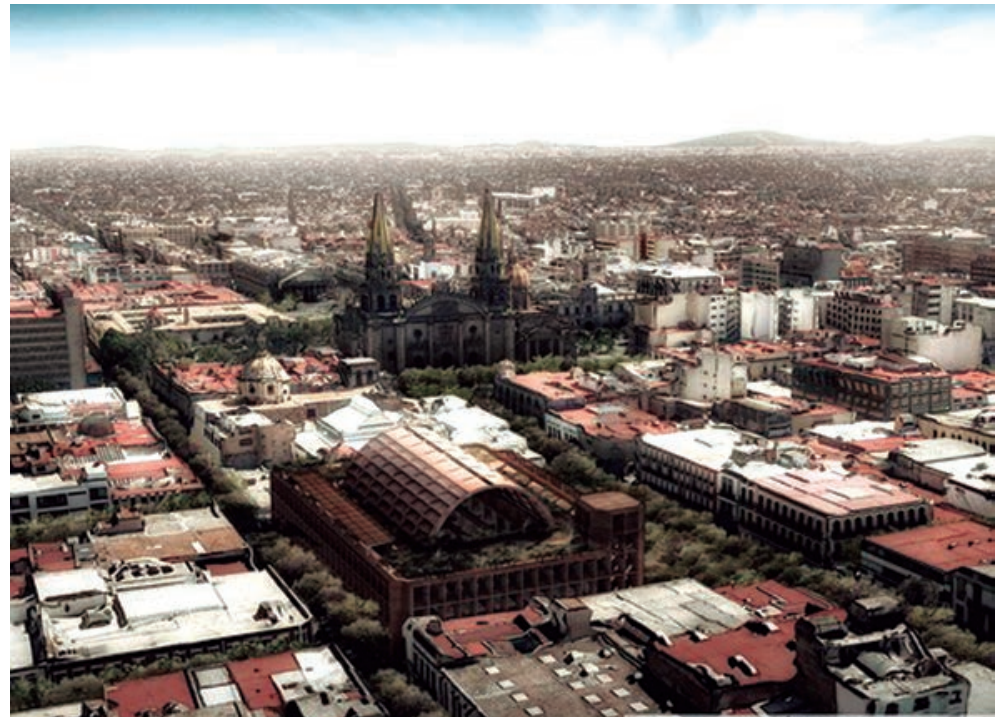

Entorno físico del mercado Corona. Fuente: Coplaur, Guadalajara.

En esta nueva propuesta se aprecia principalmente el trabajo del arquitecto y su formación estética; el contexto pierde vida y se muestra plano y vacío. La presencia de la catedral es la única referencia el contexto actual, además del elemento funcional del paso a desnivel.

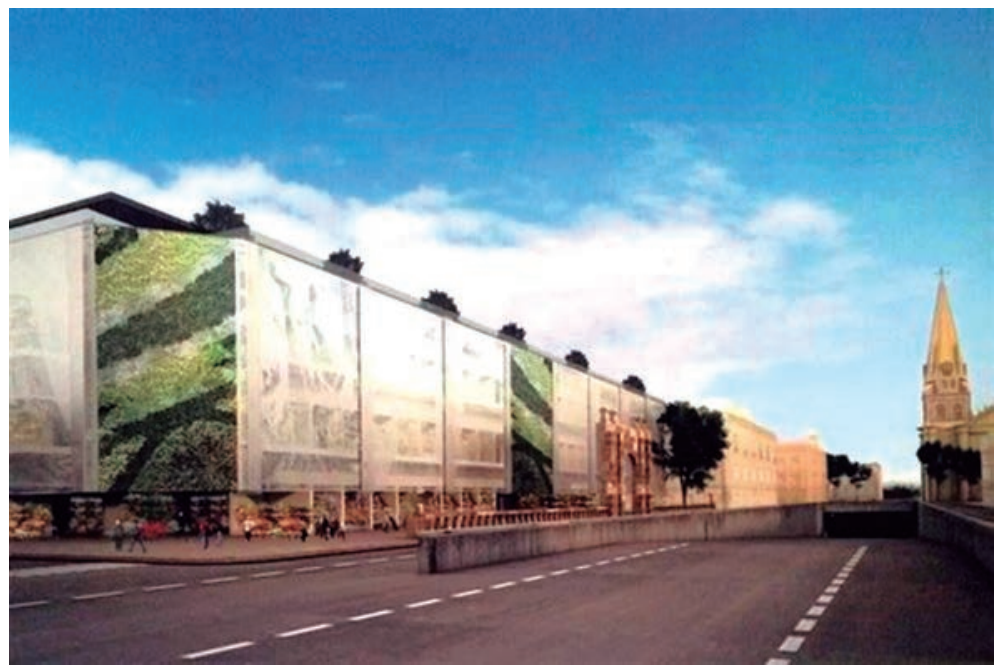

Fuente: Coplaur, Guadalajara. 
En la siguiente propuesta también se alcanza a ver la catedral, pero el contexto prácticamente desaparece, en aras de una idea muy distinta a las dinámicas sociales que se producían en los alrededores del mercado antes del incendio. Es un entorno aburguesado, con símbolos de la vida contemporánea en una ciudad cosmopolita.

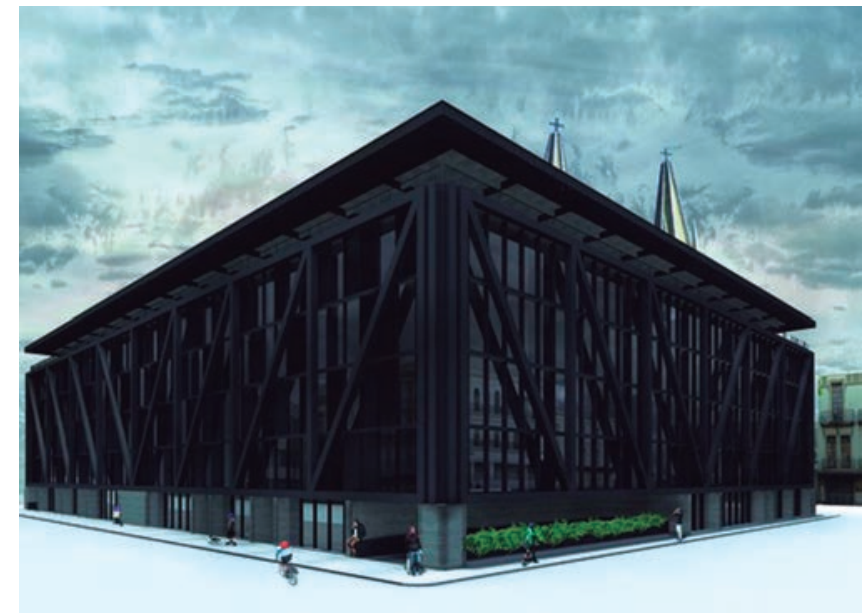

Fuente: Coplaur, Gudadalajara.

En las propuestas que siguen hay un dislocamiento aún más marcado, pues la obra se abstrae del contexto y pierde el sentido del lugar, entendido no solo como ubicación, sino como espacio vivido y construido socialmente.

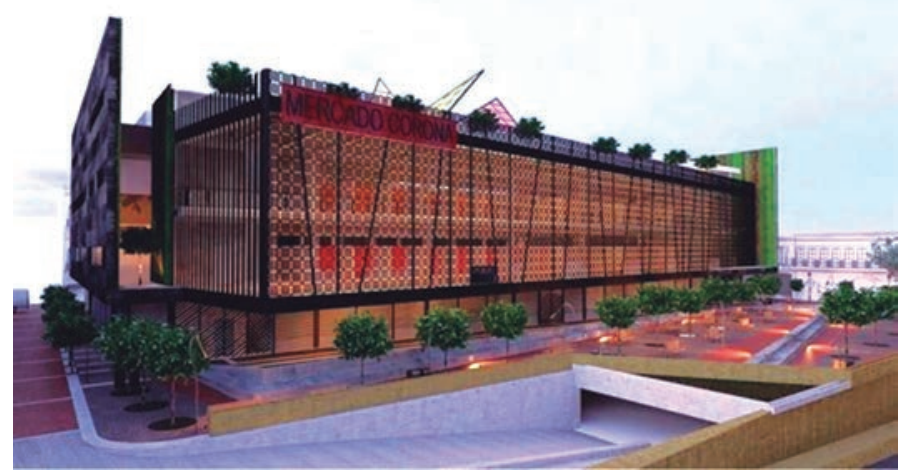

Fuente: Coplaur, Guadalajara. 
El paso a desnivel aparece en casi todas las propuestas, lo que muestra la forma en que se entiende la función urbana de este nuevo espacio, ya no como un lugar accesible, de conveniencia y dispuesto para el consumo, sino más bien como centro de encuentro, socialización e intercambio.

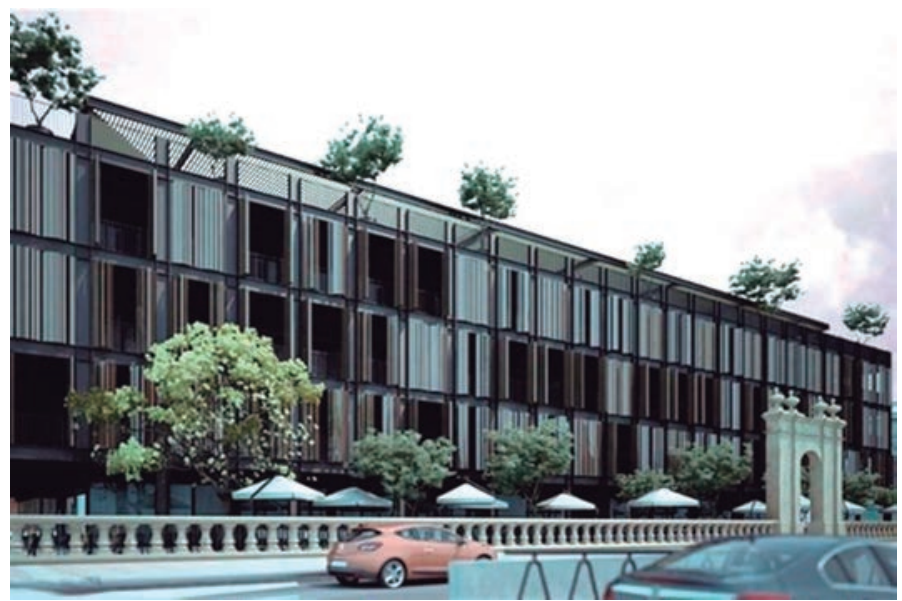

Fuente: Coplaur, Guadalajara.

En la siguiente propuesta desaparece el contexto casi por completo, salvo por la imagen al fondo de una finca de estilo colonial, que alude remotamente al centro histórico de cualquier ciudad.

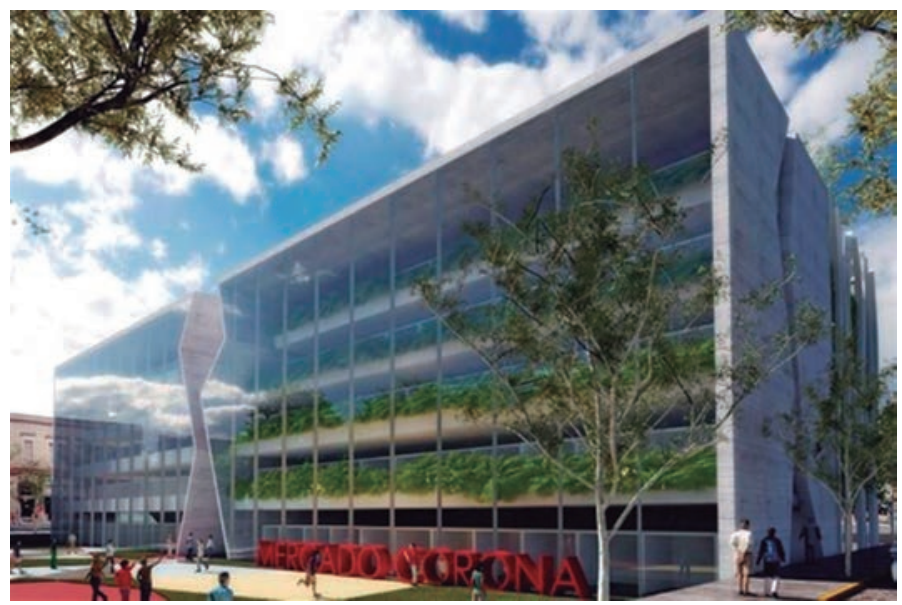

Fuente: Coplaur, Guadalajara. 
En esta imagen no solo se ignora, sino que se banaliza el contexto. Lo que rodea a la pieza arquitectónica propuesta son solo volúmenes blancos; está alrededor, pero no se considera trascendente.

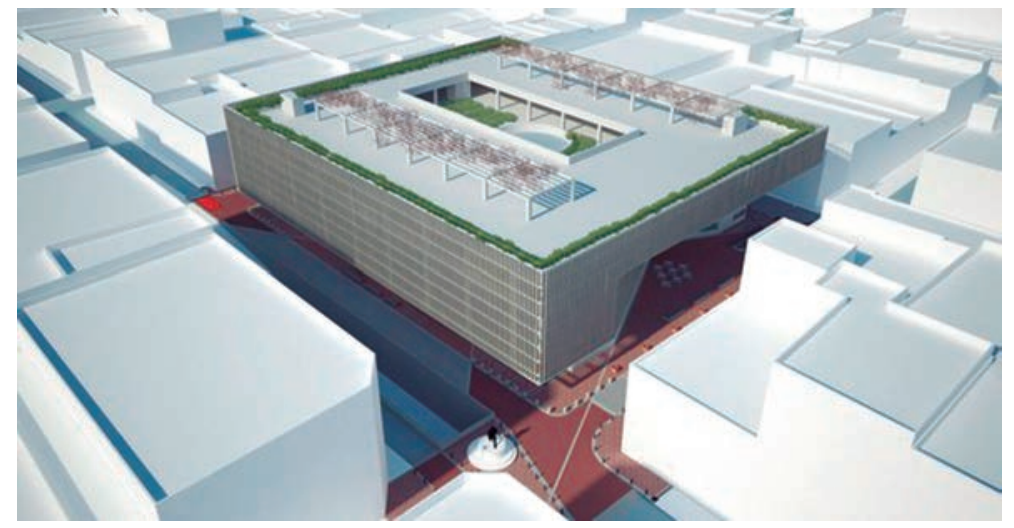

Fuente: Coplaur, Guadalajara.

En esta imagen, el edificio está fuera de todo contexto espacial y social; no se puede determinar ni siquiera de qué país se trata. La dislocación abarca no únicamente a la obra, sino también las personas, con las que se proyecta una imagen aspiracional gentrificadora.

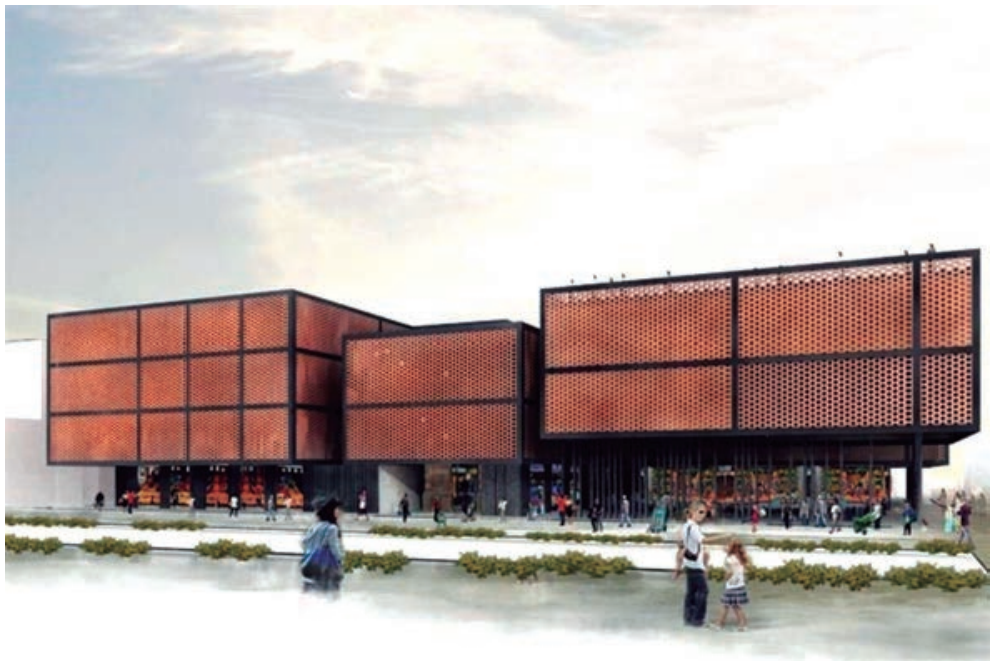

Fuente: Coplaur, Guadalajara. 
NOTAS

Con la siguiente propuesta cabe preguntarse cómo construye la práctica arquitectónica su idea estética materializada en la pieza que pretende insertar al margen del lugar y de su sentido histórico y social. La disposición del espacio, los volúmenes blanqueados y los personajes son totalmente ajenos al extinto Mercado Corona.

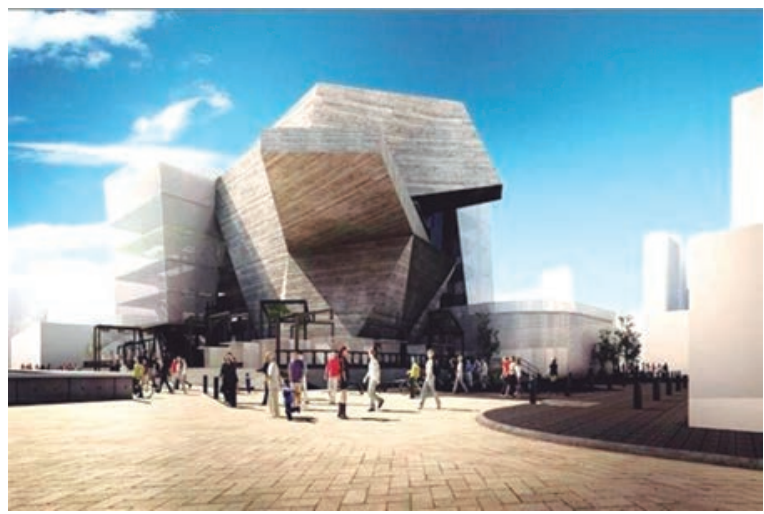

Fuente: Coplaur, Guadalajara.

La última propuesta remite a una ensoñación fuera del mundo real. La imagen surrealista de un niño pescando en el centro del "mercado" refleja qué tan lejos pueden llegar los dislocamientos cuando se trata de propuestas arquitectónicas.

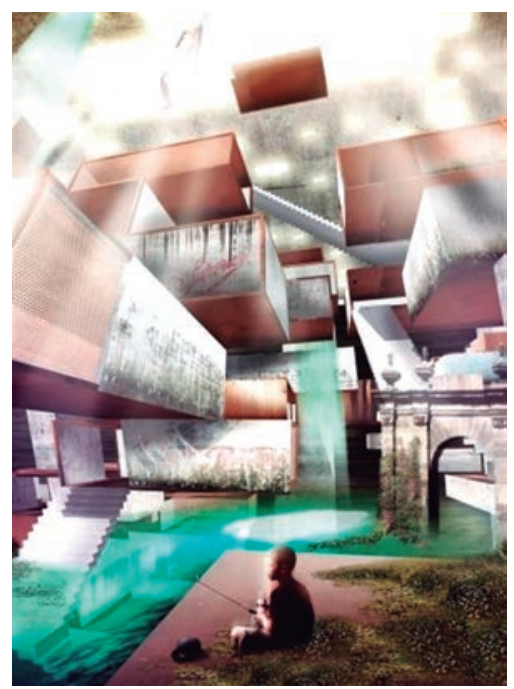

Fuente: Coplaur, Guadalajara. 
Finalmente, la propuesta ganadora, que plantea convertir el mercado en un centro comercial. La lógica de lo privado impera sobre la lógica de lo público. En un mercado que tendría que ser público, la primera planta, arriba de tres niveles de estacionamiento, será para locales de franquicias, mientras que los niveles altos serán para los comerciantes que ya ocupaban un lugar. La estética jeraquizadora de los centros comerciales propone un lugar para cada cual, en función de su capacidad para dinamizar el consumo, ignorando la lógica social y cultural que dio vida al mercado durante muchos años.

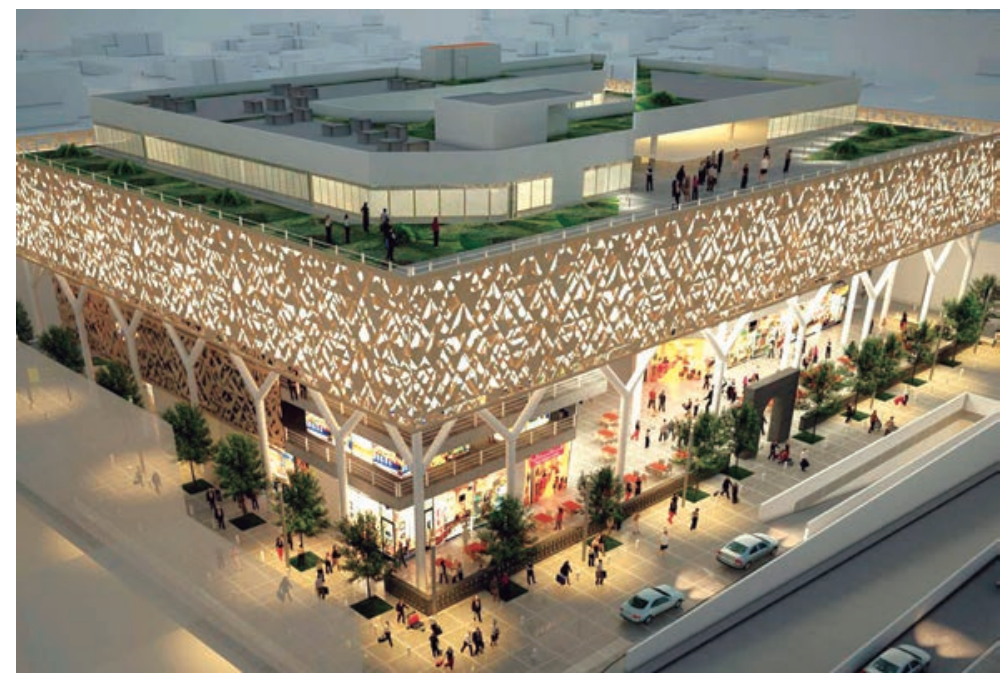

Propuesta ganadora para reconstrucción del Mercado Corona.

Fuente: Coplaur, Guadalajara.

Podemos extraer las siguientes conclusiones de este concurso: 1) en la lógica del mercado, a lo "bello" se le impone un costo de lujo, y solamente quien pueda pagarlo tiene acceso a un lugar privilegiado en estas configuraciones; 2) la variable económica fue la que determinó qué sería de este espacio y no la sociocultural; y 3) el valor del suelo condicionó la decisión y este factor dio su forma final al mercado. La estética del proyecto es resultado de la interacción de las fuerzas políticas y económicas, principalmente, y en menor medida, las sociales y populares. 
Veamos por último una experiencia similar, que ocurrió en otra intervención del espacio público, y las consecuencias que tuvo para el comercio popular que se desenvolvía en el sitio. La siguiente fotografía es del Santuario de Nuestra Señora de Guadalupe, en el centro histórico de Guadalajara. En la parte baja de la imagen se observa que hay vendedores ambulantes.

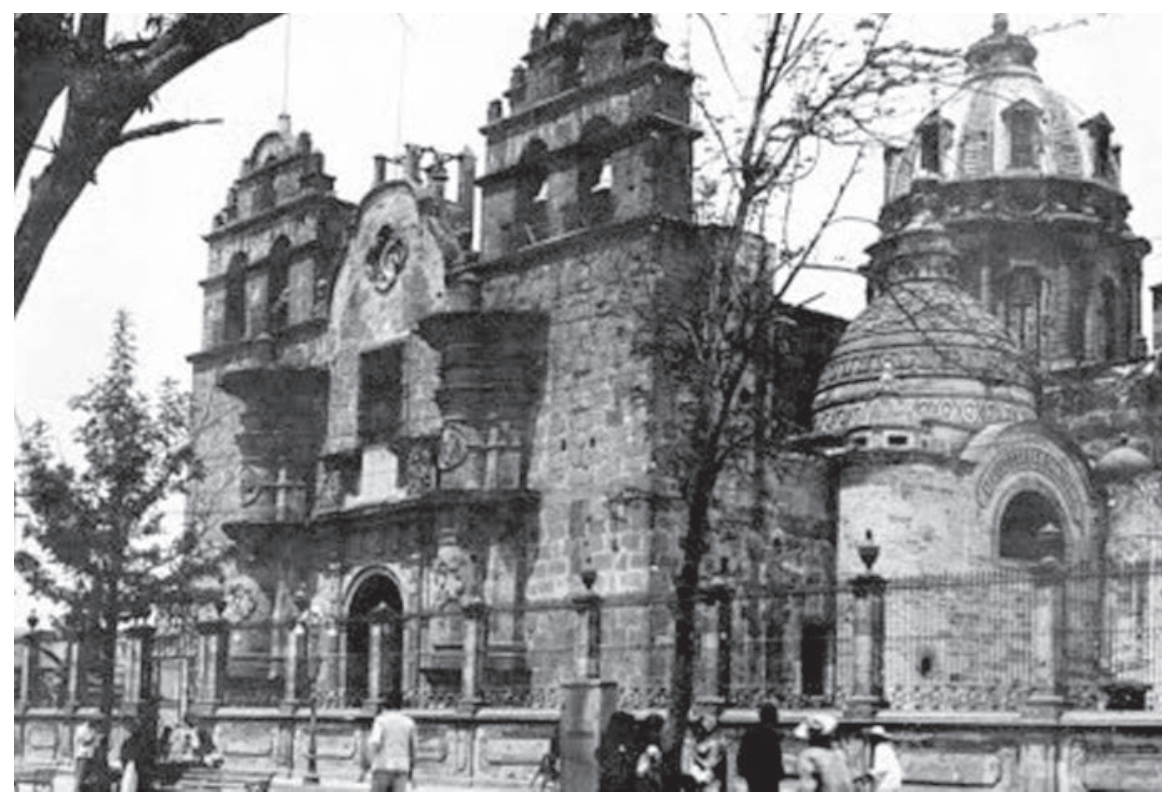

Templo del Santuario. Guadalajara, 1950.

Fuente: Ayuntamiento de Guadalajara.

La propuesta ganadora para intervenir la explanada del santuario fue exhibida y elogiada en exposiciones de arquitectura en Venecia y Hungría. En ninguna de las imágenes de la propuesta ganadora se reconoció la presencia del comercio en el espacio público, sino que fue negada. Tras la intervención física de la propuesta ganadora, el comercio popular se volvió nómada y precario en ese espacio. 


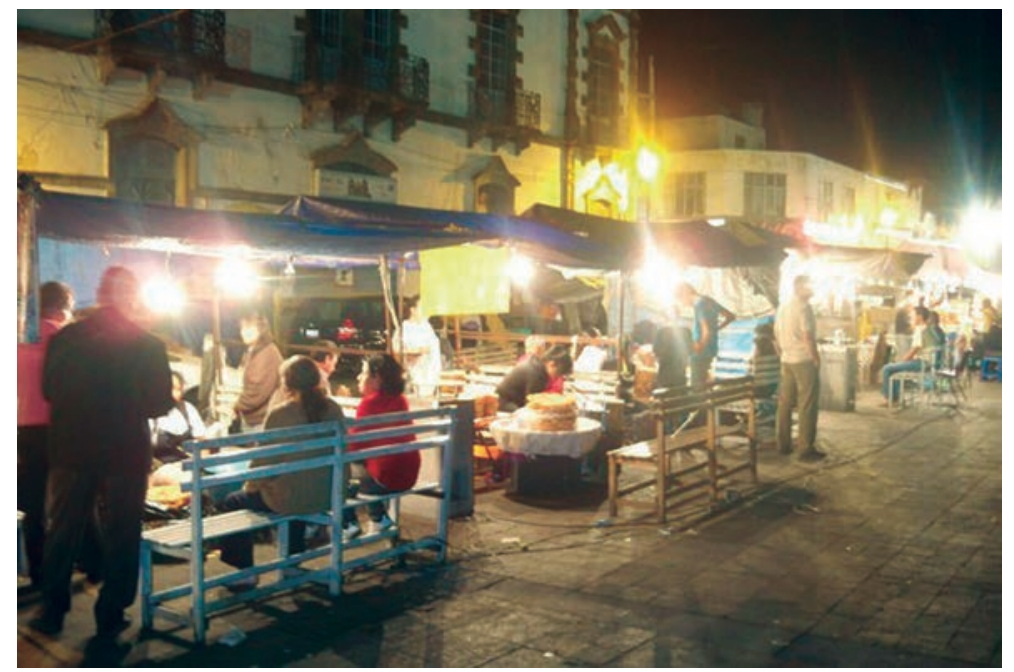

Comerciantes de buñuelos y cañas en la renovada Plaza del Santuario. Fuente: Héctor Castañón.

A contracorriente, las presencias nómadas en el escenario urbano constituyen su propio sentido estético. En la siguiente imagen, vemos la representación de un niño indígena urbano, que recoge su herencia cultural para reconstruir su cosmovisión en el contexto citadino. Así, se produce una hibridación estética que lucha y resiste para mantenerse en el espacio continuamente disputado de la ciudad. Lo mismo ocurre con las juventudes expulsadas del espacio social y productivo, con los manifestantes desplazados del espacio político de toma de decisiones, con los adultos mayores y otras poblaciones marginadas por la estética organizadora del poder, que se apoderan de su espacio y le confieren un sentido de inclusión y diversidad. 
Se prohíbe su reproducción total o parcial por cualquier medio, incluido electrónico, sin permiso previo y por escrito de los editores.

\section{NOTAS}

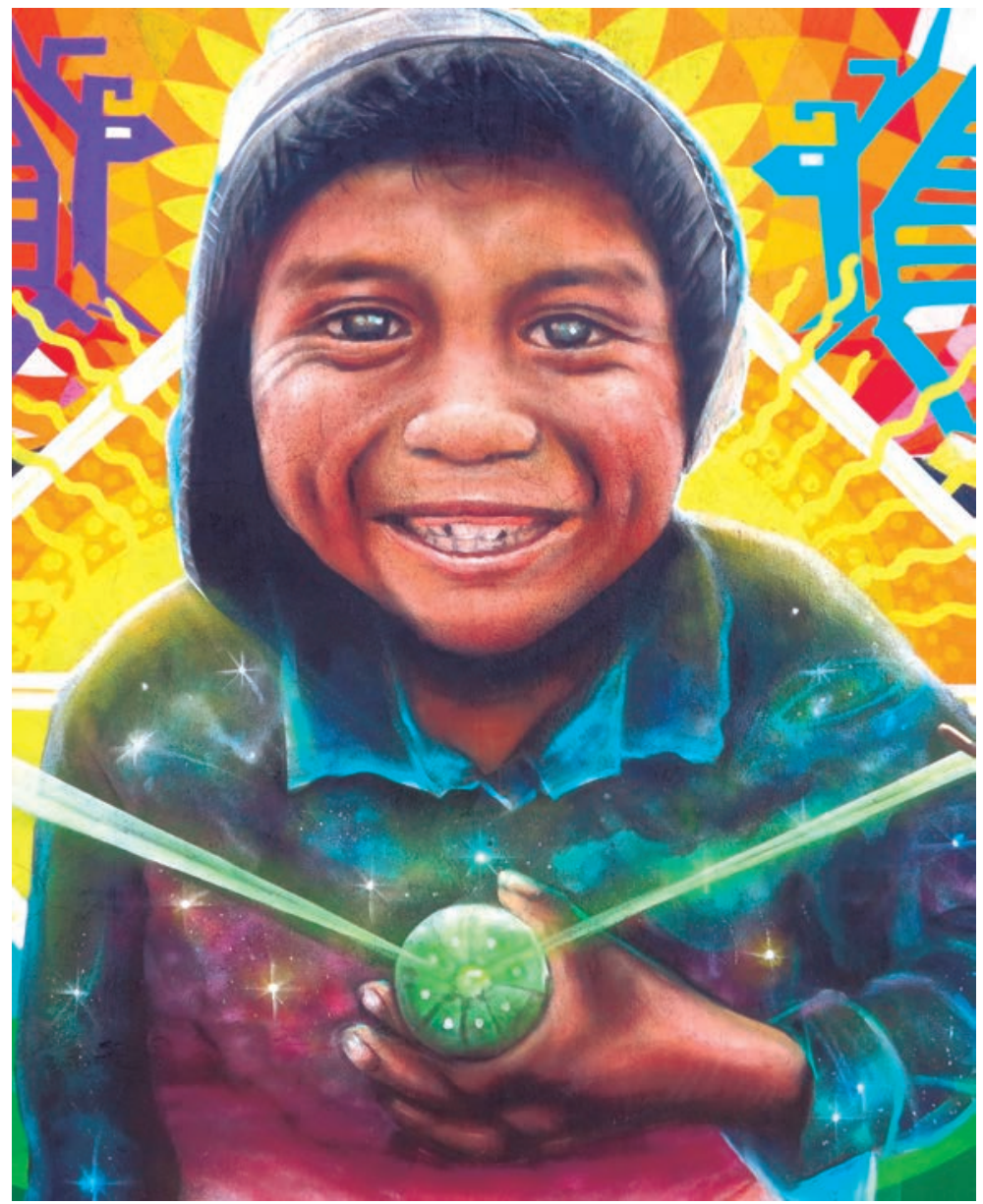

Mural en Avenida Federalismo, Guadalajara.

Fuente: Héctor Castañón. 
No todo lo que es bello en la ciudad lo es porque corresponda a su lugar y reproduzca su armonía. Los dislocamientos son también desbordamientos que el orden instituido no alcanza a contener, y al resignificar el sentido estético de la comunidad, resignifican también el lugar y sus relaciones sociohistóricas. Habría que desentrañar cómo se define lo visible en cada época histórica con las imágenes que proyecta. La ciudad bella sería la que se construye mediante creaciones colectivas dialógicas a partir del encuentro de sensibilidades. Lo informal puede entenderse como aquello que aún no tiene forma y que busca elaborar narrativas estéticas desde lugares no hegemónicos.

Terminemos con esta imagen de un trabajo de Corona, ${ }^{4}$ que da la cámara a los indígenas de la ciudad para que sean ellos los que se fotografíen como se ven en este escenario. Lo que muestra el ejercicio es que, al final, resulta importante equilibrar la imagen con narraciones visuales que democraticen y expresen la versión de las poblaciones excluidas. Las fotografías de Corona muestran cómo quieren ser vistos los jóvenes wixaritaris. Son jóvenes apuestos, sanos, divertidos, actuales. En esta ocasión la cámara otorga a la joven fotógrafa, indígena, una nueva posición productiva: se ha transformado de ser un objeto a ser un sujeto con nuevas técnicas de poder de visibilidad.

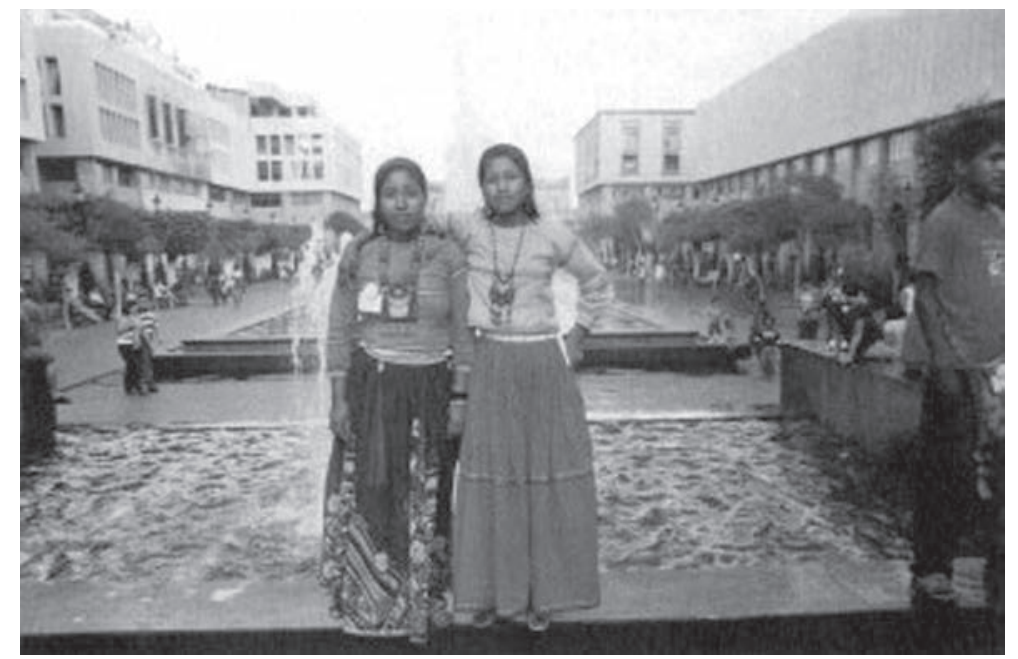

Mujeres wixaritaris por mujer wixárika. Fuente: Blanca de la Cruz de la Cruz. 
Se prohíbe su reproducción total o parcial por cualquier medio, incluido electrónico, sin permiso previo y por escrito de los editores. 